\title{
Comparative cytotoxicity of phenols in vitro
}

\author{
Siro PASSI, Mauro PICARDO and Marcella NAZZARO-PORRO \\ Istituto Dermatologico San Gallicano, Roma, Italy
}

\begin{abstract}
Two melanotic human melanoma cell lines, IRE 1 and IRE 2, and the lymphoma- and leukaemia-derived

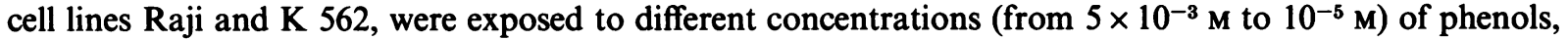
both substrates (s) and non-substrates (ns) of tyrosinase, in the presence or absence of the oxygenradical-scavenger enzymes superoxide dismutase, catalase and peroxidase. Monophenols were tyrosine (s), 4-hydroxyanisole (s) and butylated hydroxyanisole (ns); diphenols were L-3,4-dihydroxyphenylalanine (s), dopamine (3,4-dihydroxyphenethylamine) (s), terbutylcatechol (s), hydroquinone (s) and resorcinol (ns); triphenols were 6-hydroxydopa (3,4,6-trihydroxyphenylalanine) (s) and methyl gallate (s). Triphenols and $o$ and $p$-diphenols underwent complete oxidation in culture medium within $24 \mathrm{~h}$ of incubation and were significantly more toxic than monophenols and the $m$-diphenol resorcinol, which, under the same cultural conditions, were much more stable. No significant differences in percentage survival were found among the different cell lines for each drug tested. The major component of toxicity up to $24 \mathrm{~h}$ of di- and tri-phenols is due to toxic oxygen species acting outside the cells and not to cellular uptake of these phenols as such. In fact the addition of oxygen-radical-scavenger enzymes significantly $(P<0.01)$ decreased the adverse effect of these drugs on all cell lines. The lower toxicity of monophenols and resorcinol as compared with that of di- and tri-phenols is due, in our opinion, to the fact that they are less oxidized under the conditions existing in the culture medium, and therefore do not produce sufficient levels of oxygen radicals. For these compounds, a primary intracellular action has to be taken into account to explain their cytotoxicity.
\end{abstract}

\section{INTRODUCTION}

In recent years several investigations have been directed at examining the potential anti-melanoma effect of phenols (Wick, 1977, 1978, 1979, 1980a,b, 1982; Wick \& Frei, 1977; Wick et al., 1977, 1980; Pawelek \& Lerner, 1978; Fujita et al., 1980; Parson \& Morrison, 1982; Fitzgerald \& Wick, 1983, 1986; Pawelek \& Murray, 1986). Although initial studies tended to correlate the melanocytotoxic effect with data relating to the action of tyrosinase in vitro, it has been demonstrated that several of these phenolic agents possess a number of other actions affecting cell functions unrelated to melanogenesis. These are DNA synthesis, mitochondrial respiration, RNA reductase and microsomal mixed-function oxidase, interference with which may account for the general cytotoxic effect (Wick, 1979, 1980a,b; Fitzgerald \& Wick, 1983, 1986; Passi et al., 1985; Riley, 1985). Although it is probable that some of the observed actions of these compounds are due to direct interference with certain cellular functions, many of the most active cytotoxic substances share the property of being relatively easily oxidized, and may exert their toxic effect through the action of oxidation products. Some phenols are, in fact, so readily oxidized in cellular cultures that their main toxic action appears to result from extracellular autoxidation with the generation of toxic oxygen species (Parson, 1985; Picardo et al., 1987).

Generally, the capacity for autoxidation depends on the number and steric position of hydroxy groups, the electronic properties and position of possible substituents on the benzene ring, and, consequently, the polarity.
Thus 6-hydroxydopa is more easily autoxidizable and polar then dopa, and this much more so than L-tyrosine.

Cellular permeability is a significant factor that is often disregarded in studies concerning cytotoxicity in cultures. Many of the phenols, in fact, possess a chemical structure and solubility properties that would enable them to enter cells readily and be oxidized by a variety of metabolic routes.

The present work deals with the comparative cytotoxicity of phenols (mono-, di- and tri-phenols), which are substrates or non-substrates of tyrosinase (Passi \& Nazzaro-Porro, 1981), on different cell lines containing or not containing tyrosinase. In addition, we have explored the possibility that scavenger enzymes may interfere with the cytotoxic effect of phenols.

\section{MATERIALS AND METHODS}

\section{Cultures}

Four established cell lines were used in the present study: the lymphoma-derived Raji cell line (Dr. Ragona, Department of General Pathology, University of Rome, Rome, Italy), the erythroleukaemia cell line K 562 (Professor R. Heberman, National Cancer Institute, Bethesda, MD, U.S.A.) and two melanotic human melanoma cell lines IRE 1 and IRE 2 (Dr. P. G. Natali, R. Elena Institute, Rome, Italy). All the cell lines were cultured in RPMI 1640 medium (GIBCO), with $10 \%$ (v/v) fetal-calf serum (GIBCO), penicillin (100 units $/ \mathrm{ml}$ ), and streptomycin $(100 \mu \mathrm{g} / \mathrm{ml})$. Every 3 days the medium was removed and the cells subcultured. For the

Abbreviations used: HQ, hydroquinol; dopa, L-3,4-dihydroxyphenylalanine; dopamine, 3,4-dihydroxyphenethylamine; BHA, butylated hydroxyanisole; MG, methyl gallate (3,4,5-trihydroxybenzoic acid methyl ester); RES, resorcinol; TBC, terbutylcatechol; SOD, superoxide dismutase; PER, peroxidase; CAT, catalase; 4-OHA, 4-hydroxyanisole. 
experiments, $(2-3) \times 10^{4}$ cells/well were seeded on 96-well plates (Flow Laboratories) (the suspended cell lines Raji and $K$ 562) or in 24-well plates (Flow) (IRE 1 and IRE 2). Cells were cultured for 2, 4, 6, 8, 12, 20, 24 and $48 \mathrm{~h}$ at $37^{\circ} \mathrm{C}$ in $\mathrm{CO}_{2} /$ air $(1: 19)$ in the presence or absence of different phenols. Cultures were pulsed 1-4 h with $\left[{ }^{3} \mathrm{H}\right]$ thymidine. The suspended cell lines were harvested by using a cell harvester (Titertek) and the radioactivity was counted in a $\beta$-radiation counter. In the case of cultured melanoma cell lines, cells were washed and precipitated with $10 \%(\mathrm{w} / \mathrm{v})$ trichloroacetic acid for $4 \mathrm{~h}$ at $4{ }^{\circ} \mathrm{C}$. The precipitate was washed twice in saline $(0.9 \% \mathrm{NaCl})$, followed by the addition of $1 \mathrm{M}-\mathrm{NaOH}$ and left at $4{ }^{\circ} \mathrm{C}$ for $24 \mathrm{~h}$. Scintillation fluid (Unisolve) was added and the sample counted for radioactivity.

\section{Phenols}

HQ, dopa, dopamine, 4-OHA, BHA, L-tyrosine and MG were obtained from Fluka; RES and TBC were from Merck AG; 6-hydroxydopa was from Sigma. All these compounds were of the highest grade available, and were used at concentrations ranging from $10^{-5} \mathrm{M}$ to $5 \times 10^{-3} \mathrm{M}$.

Their toxicity was also tested in the presence of 100 units of SOD $/ \mathrm{ml}$ and/or 1 unit of PER/ml and/or 1 unit of CAT $/ \mathrm{ml}$. All these scavenger enzymes were purchased from Sigma.

\section{Stability of phenols}

The stability of phenols in complete medium at $37^{\circ} \mathrm{C}$ up to 2 days, in the absence or presence of different cell lines and scavenger enzymes, was evaluated by h.p.l.c. on an RP18 $5 \mu \mathrm{m}$ column (Passi \& Nazzaro-Porro, 1981; Passi et al., 1985).

\section{Effect of preincubation of phenols on cell survival}

Experiments were performed in order to investigate the effect of the preincubation of phenols on cell survival. The different cell lines were incubated after the previous addition of phenols to culture medium for 24 or $48 \mathrm{~h}$, and the toxicity was evaluated as described above.

\section{Cellular uptake of $\left[{ }^{3} \mathrm{H}\right] 4-\mathrm{OHA}$ and $\left[{ }^{3} \mathrm{H}\right] \mathrm{dopa}$}

Cell lines $\left(10^{6}\right.$ cells $\left./ \mathrm{ml}\right)$ were cultured for $1 \mathrm{~h}$ at $37^{\circ} \mathrm{C}$ in the presence of: (1) $10 \mu \mathrm{Ci}$ of $\left[1-\right.$ methoxy $\left.-{ }^{3} \mathrm{H}\right] 4-\mathrm{OHA}$ (sp. radioactivity $10 \mathrm{mCi} / \mathrm{mmol}$; kindly provided by Professor P. A. Riley, Department of Biochemical Pathology, School of Medicine, University College, London, U.K.) plus $10^{-3} \mathrm{M}$ unlabelled 4-OHA; (2) $5 \mu \mathrm{Ci}$ of L-3,4-dihydroxy[ring-2,5,6- $\left.{ }^{3} \mathrm{H}\right]$ phenylalanine (sp. radioactivity $25 \mathrm{Ci} / \mathrm{mmol}$; obtained from The Radiochemical Centre, Amersham, Bucks., U.K.) plus $5 \times 10^{-4} \mathrm{M}$ unlabelled dopa. $\left[{ }^{3} \mathrm{H}\right]$ Dopa was kept at $-20^{\circ} \mathrm{C}$ at pH 3 to prevent its decomposition, and immediately before experiments it was purified by h.p.l.c. and its radioactivity checked in a $\beta$-radiation counter. The cells were washed four times with phosphate-buffered saline (Flow), pH 7.4, and then counted for radioactivity. Blanks contained the same cells to which had been added, immediately before washing, $10 \mu \mathrm{Ci}$ of [ $\left.{ }^{3} \mathrm{H}\right] 4-\mathrm{OHA}$ plus $10^{-3} \mathrm{M}$ unlabelled 4-OHA, or $5 \mu \mathrm{Ci}$ of just-prepared $\left[{ }^{3} \mathrm{H}\right]$ dopa plus $5 \times 10^{-4} \mathrm{M}$ unlabelled dopa, or $5 \mu \mathrm{Ci}$ of $\left[{ }^{3} \mathrm{H}\right]$ dopa plus $5 \times 10^{-4} \mathrm{M}$-dopa preincubated for $24 \mathrm{~h}$.

\section{RESULTS}

\section{Stability of phenols}

Fig. 1 shows the rate of decomposition of $0.1 \mathrm{~mm}$-tri-, di- and mono-phenols in complete culture medium. The presence of cell lines did not affect the rate of decomposition. The triphenol 6-hydroxydopa is much more rapidly autoxidized than the other phenols. Autoxidation of the $o$-diphenols TBC and DPA (not shown in Fig. 1) paralleled that of HQ and dopa respectively. Also, the decomposition of the triphenol MG was similar to that of dopa. Paralleling the gradual disappearance with the time of the above drugs, no quinone formation was detectable by h.p.l.c. analysis on a reversed-phase column.

The monophenols tyrosine, 4-OHA and BHA, and the $m$-diphenol RES, were more stable: only $10-15 \%$ became

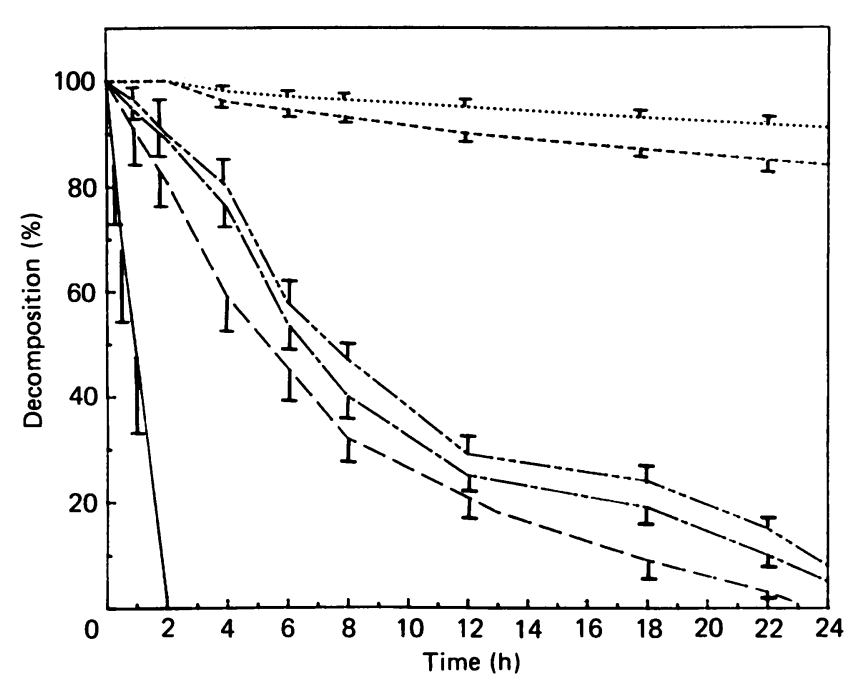

Fig. 1. Rate of decomposition of $0.1 \mathrm{mM}-$ tri-, di- and monophenols in culture medium

Each point represents the average for five analyses. Bars represent S.D. $-\frac{}{-}$, 6-Hydroxydopa; ----, HQ; -- dopa; ---- MG; -----, 4-OHA; $\cdots \cdots$, , tyrosine. For further details, see the text.

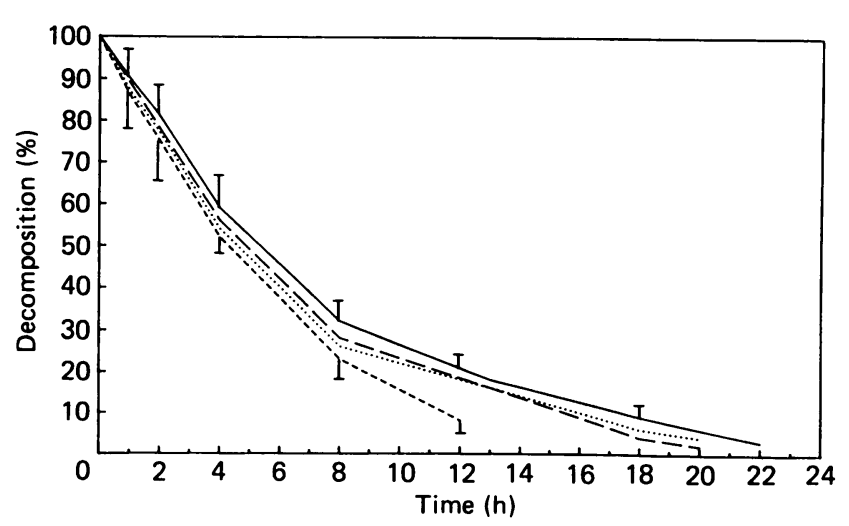

Fig. 2. Rate of decomposition of $0.1 \mathrm{mM}-\mathrm{HQ}$ in culture medium

Each point represents the average for five analyses. Bars represent S.D. ——, Without enzymes; ----, plus SOD; -.---, plus PER; $\cdots \cdots$, plus CAT. The same behaviour was observed in the case of $o$-di- and tri-phenols. For further details, see the text. 
decomposed after $48 \mathrm{~h}$ of incubation, in both the presence and absence of cell lines. The rates of decomposition of BHA and RES are not shown in Fig. 1.

PER and, to a lesser extent, CAT and SOD, both alone and in the presence of cells, accelerated the decomposition of triphenols and $o$ - and $p$-diphenols (Fig. 2), but not that of the monophenols BHA, 4-OHA and tyrosine, or the $m$-diphenol RES.

\section{Toxic effect of phenols}

Figs. 3-4 show the effect of different concentrations of phenols on the percentage survival of Raji and IRE 1 cell lines after 24 and $48 \mathrm{~h}$ of incubation. For each phenol tested, the toxicity increased with the duration of culture up to $48 \mathrm{~h}$ (Picardo et al., 1987). From Table 1, which summarizes this effect, it is evident that no significant variation in the level of survival was found among the different cell lines for each drug tested. However, the triphenol 6-hydroxydopa was more toxic than were the

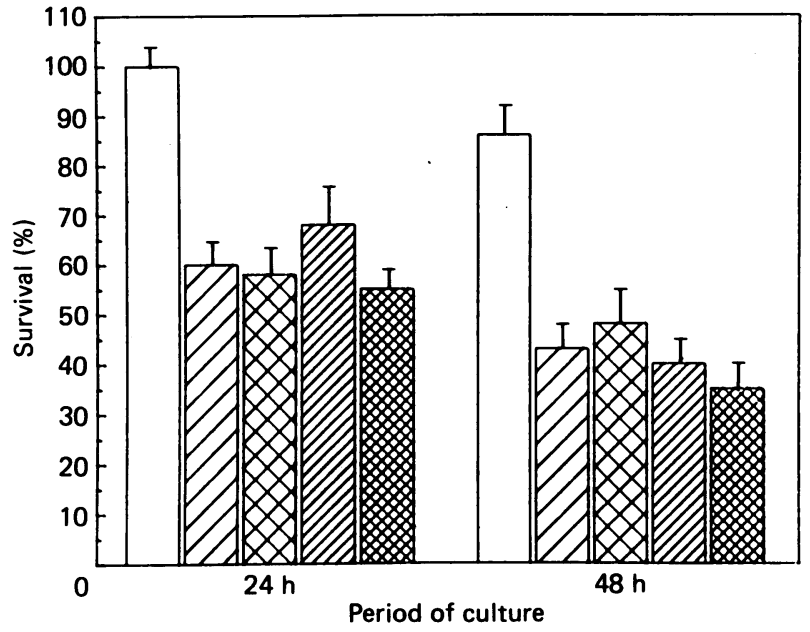

Fig. 3. Effect of different phenols on the Raji cell line

Each point represents the average for five experiments performed in quadruplicate. Bars represent S.D. $\square$, 1 mM-Tyrosine; $\square, 1$ mM-4-OHA; $\otimes, 0.1$ mM-dopa; $0.01 \mathrm{~mm}-\mathrm{HQ} ; \mathbf{8}, 0.01 \mathrm{~mm}-6$-hydroxydopa. dihydric phenols dopa, DPA, HQ and TBC, and the triphenol MG, and these more than the monophenols and RES.

It is noteworthy that the level of toxicity of BHA, which is not a substrate of tyrosinase, was significantly higher $(P<0.05)$ than that of 4-OHA, which is a substrate of tyrosinase (Passi \& Nazzaro-Porro, 1981).

The addition to the medium of oxygen-radicalscavenger enzymes, such as SOD, CAT and PER, only slightly affected the toxicity towards Raji and IRE 1 cell lines of RES and the monophenols tyrosine, 4-OHA and BHA, which are stable drugs. In contrast, the enzymes greatly decreased $(P<0.01)$ the adverse effect of $o$ - and $p$-diphenols and triphenols (Figs. 5-6), which are very unstable drugs. The effect was partly additive when these scavenger enzymes were used concomitantly and persisted for about $24 \mathrm{~h}$ (Table 2). The same behaviour was observed with the other cell lines.

The effects of preincubation of phenols on cell viability were also determined. Fig. 7 shows the

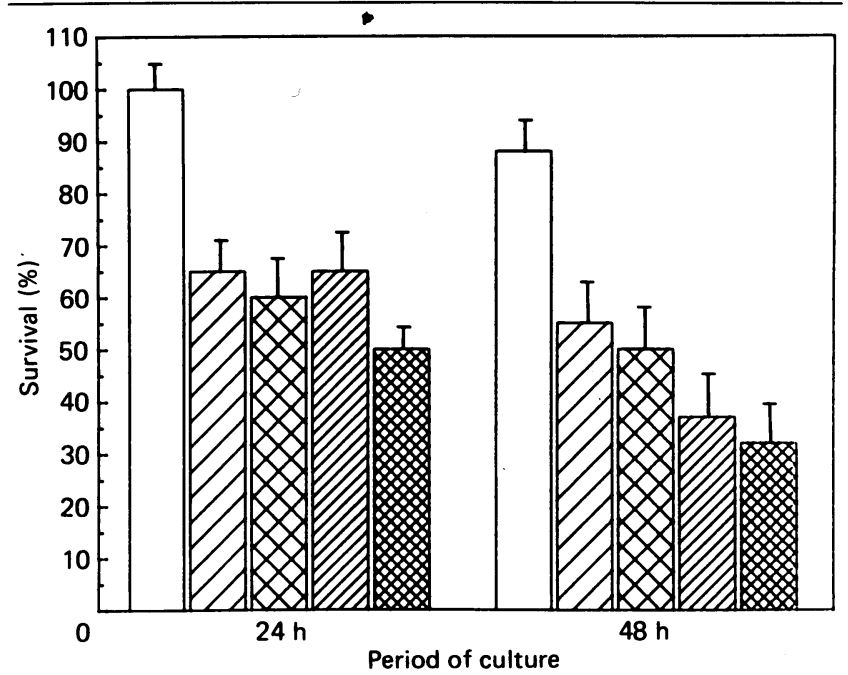

Fig. 4. Effect of different phenols on the IRE 1 cell line

Each point represents the average for five experiments performed in quadruplicate. Bars represent S.D. $\square$,

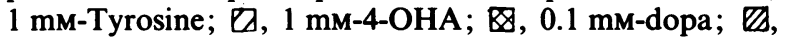
$0.01 \mathrm{~mm}-\mathrm{HQ}$; $0.01 \mathrm{~mm}-6-\mathrm{hydroxydopa}$.

Table 1. Percentage survival of Raji, K 562, IRE 1 and IRE 2 cell lines cultured in the presence of different phenols for $24 \mathrm{~h}$

Each result represents the mean \pm S.D. for five experiments performed in quadruplicate. The phenols are reported in decreasing order of toxicity. TBC and DPA toxicities were not reported because they are similar to those of HQ and DOPA respectively. Abbreviation 6-OH-, 6-hydroxy.

Percentage survival

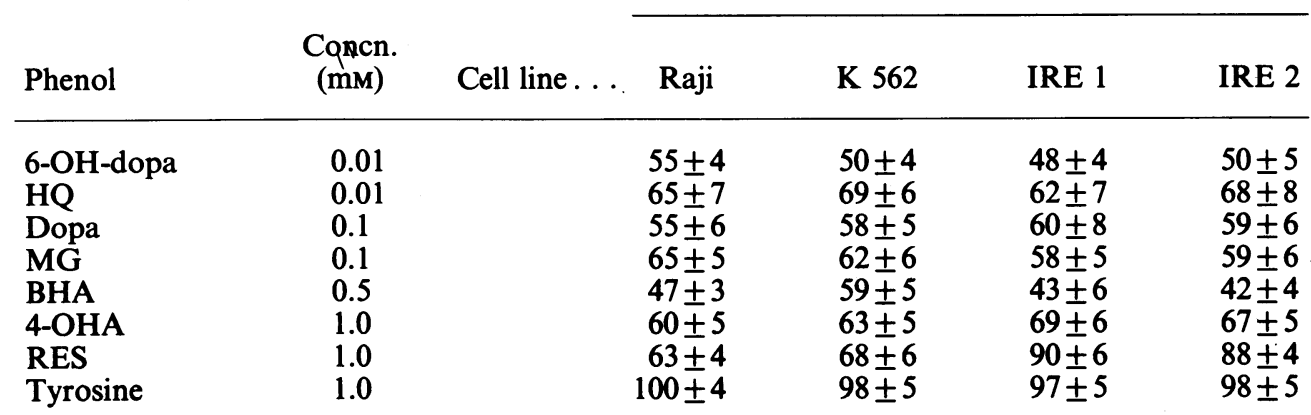

Vol. 245 
decreased survival of the IRE 1 cell line cultured for $24 \mathrm{~h}$ in the presence of mono-, di- and tri-phenols which had been preincubated in the medium for 24 and $48 \mathrm{~h}$. During this period, both triphenols and diphenols entirely disappeared from the medium. It is evident that the preincubation significantly affected $(P<0.01)$ cell survival, and did so to a greater extent than when phenols were not preincubated. The other cell lines behaved in the same way as the IRE 1 cells. Preincubation, however, did not influence the toxicity of BHA, 4-OHA, tyrosine and RES.

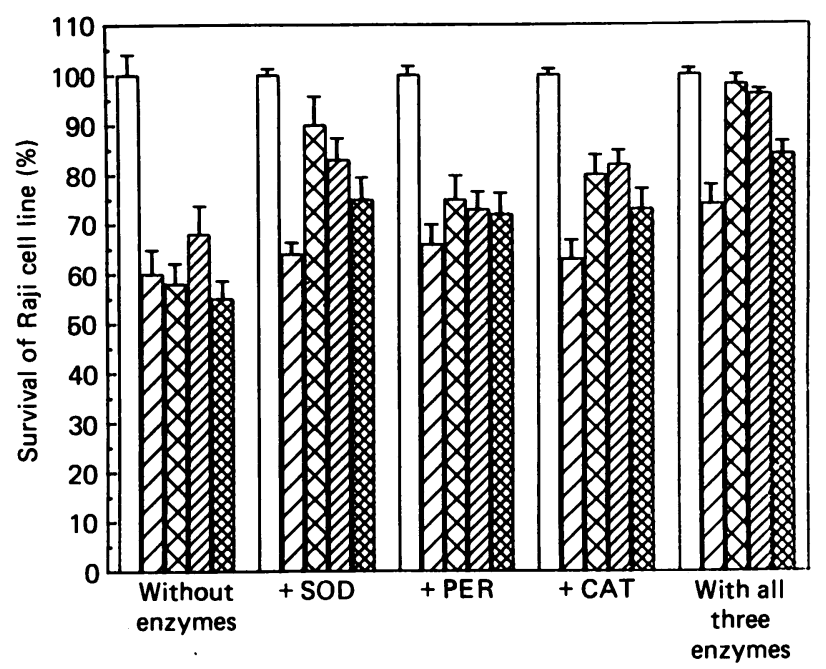

Fig. 5. Effect of oxygen-radical-scavenger enzymes on phenol toxicity towards the Raji cell line

Each point represents the average for five experiments performed in quadruplicate. Bars represent S.D. $\square$, 1 mM-Tyrosine; $\Xi, 1$ mM-4-OHA; 8 , 0.1 mM-dopa; $\square$, $0.01 \mathrm{~mm}-\mathrm{HQ} ;$ 国, $0.01 \mathrm{~mm}$-6-hydroxydopa. For further details, see the text.

\section{Cell uptake of $\left[{ }^{3} \mathrm{H}\right] 4-\mathrm{OHA}$ and $\left[{ }^{3} \mathrm{H}\right] \mathrm{dopa}$}

Values for ${ }^{3} \mathrm{H}$ uptake by different cell lines incubated for $60 \mathrm{~min}$ with $\left[{ }^{3} \mathrm{H}\right] 4-\mathrm{OHA}$ or $\left[{ }^{3} \mathrm{H}\right]$ dopa are summarized in Fig. 8. After this period, the numbers of viable cells remained unchanged. No significant differences were found between the cell lines in ${ }^{3} \mathrm{H}$ uptake from $\left[{ }^{3} \mathrm{H}\right] 4-\mathrm{OHA}$. The behaviour was the same in the presence of $\left[{ }^{3} \mathrm{H}\right] \mathrm{dopa}$. In addition, the value of ${ }^{3} \mathrm{H}$ uptake of just freshly prepared dopa paralleled that of dopa preincubated for $24 \mathrm{~h}$, when this catechol was fully decomposed.

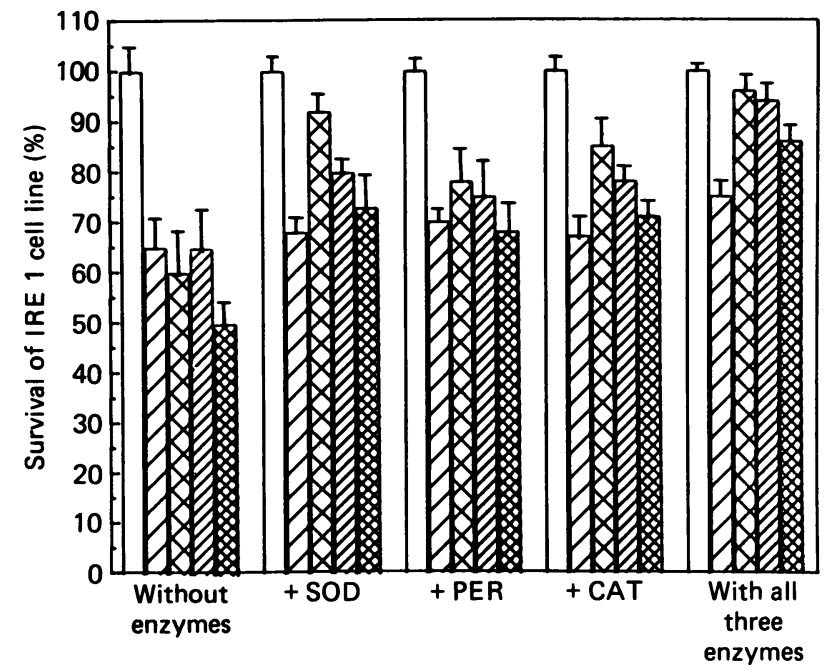

Fig. 6. Efiect of oxygen-radical-scavenger enzymes on phenol toxicity towards the IRE 1 cell line

Each point represents the average for five experiments performed in quadruplicate. Bars represent S.D. $\square$, 1 mM-Tyrosine; $\square, 1$ mM-4-OHA; $\otimes, 0.1$ mM-dopa; $\square$, $0.01 \mathrm{~mm}-\mathrm{HQ}$; $0.01 \mathrm{~mm}-6$-hydroxydopa. For further details, see the text.

Table 2. Effect of oxygen-radical-scavenger enzymes on the percentage survival of Raji and IRE 1 cell lines in the presence of $0.1 \mathrm{mM-dopa}$ or $0.1 \mathrm{mM}-\mathrm{HQ}$ preincubated in the medium for 24 and $48 \mathrm{~h}$

Each result represents the mean +S.D. for five experiments each performed in quadruplicate. Scavenger enzymes were added together with the cells. ${ }^{*}$ Indicates values were significant (at $P<0.01$ ) as compared with their respective controls.

\begin{tabular}{|c|c|c|c|c|c|}
\hline \multirow[b]{3}{*}{ Enzyme } & \multirow{3}{*}{$\begin{array}{l}\text { Preincubation } \\
\text { period } \\
\text { (h) }\end{array}$} & \multicolumn{4}{|c|}{ Percentage survival } \\
\hline & & \multicolumn{2}{|c|}{ DOPA } & \multicolumn{2}{|c|}{ HQ } \\
\hline & & Raji & IRẼ 1 & Raji & IRE 1 \\
\hline $\begin{array}{l}\text { None (control) } \\
\text { SOD }\end{array}$ & $\begin{array}{r}0 \\
0 \\
24 \\
48\end{array}$ & $\begin{array}{l}55 \pm 6 \\
90 \pm 4^{*} \\
70 \pm 7^{*} \\
36 \pm 6\end{array}$ & $\begin{array}{l}60 \pm 5 \\
92 \pm 3^{*} \\
71 \pm 4^{*} \\
36 \pm 7\end{array}$ & $\begin{array}{l}20 \pm 2 \\
65 \pm 7^{*} \\
60 \pm 6^{*} \\
20 \pm 6\end{array}$ & $\begin{array}{l}20 \pm 4 \\
55 \pm 8^{*} \\
58 \pm 9^{*} \\
18 \pm 5\end{array}$ \\
\hline PER & $\begin{array}{r}0 \\
24 \\
48\end{array}$ & $\begin{array}{l}75 \pm 6^{*} \\
55 \pm 6^{*} \\
34 \pm 5\end{array}$ & $\begin{array}{l}78 \pm 8^{*} \\
54 \pm 7^{*} \\
33 \pm 6\end{array}$ & $\begin{array}{l}40 \pm 5^{*} \\
36 \pm 4^{*} \\
13 \pm 4\end{array}$ & $\begin{array}{l}38 \pm 3^{*} \\
35 \pm 4^{*} \\
12 \pm 3\end{array}$ \\
\hline CAT & $\begin{array}{r}0 \\
24 \\
48\end{array}$ & $\begin{array}{l}80 \pm 4 \\
58 \pm 5^{*} \\
35 \pm 4\end{array}$ & $\begin{array}{l}85 \pm 6^{*} \\
61 \pm 4^{*} \\
36 \pm 8\end{array}$ & $\begin{array}{l}50 \pm 6^{*} \\
45 \pm 5^{*} \\
15 \pm 5\end{array}$ & $\begin{array}{l}48 \pm 7^{*} \\
45 \pm 3^{*} \\
16 \pm 6\end{array}$ \\
\hline
\end{tabular}




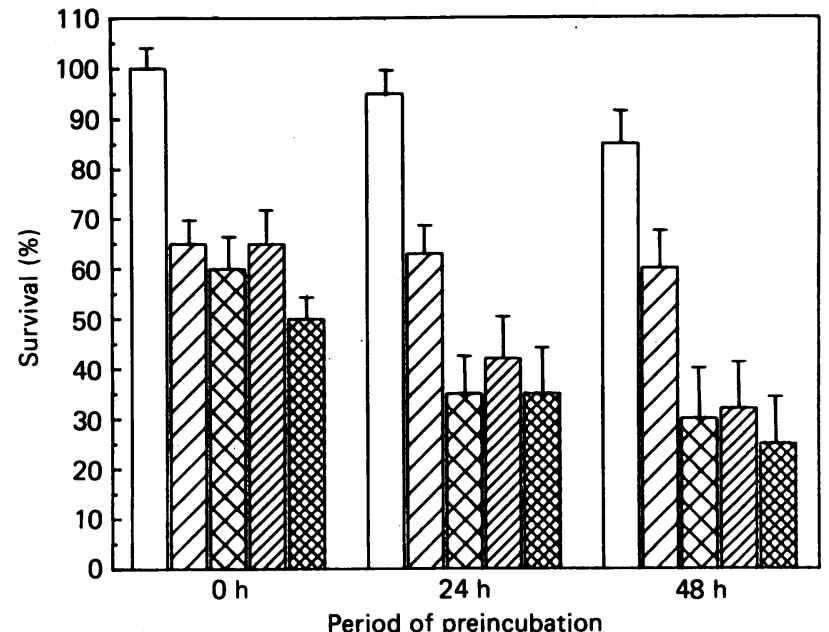

Fig. 7. Effect of preincubation of phenols on the IRE 1 cell line

Each point represents the average for five experiments performed in quadruplicate. Bars represent S.D. $\square$, 1 mM-Tyrosine; $\oslash, 1 \mathrm{~mm}$ 4-OHA; 8 , $0.1 \mathrm{mm-dopa;} \square$, $0.01 \mathrm{~mm}$-HQ;, $0.01 \mathrm{~mm}$-6-hydroxydopa.

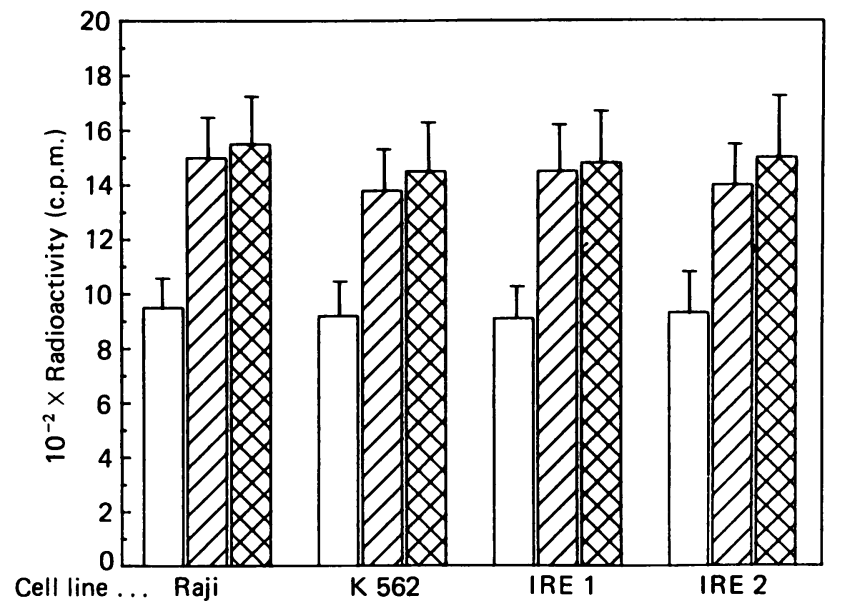

Fig. 8. ${ }^{3} \mathrm{H}$ uptake by different cell lines incubated for $60 \mathrm{~min}$ with $\left[{ }^{3} \mathrm{H}\right] 4-\mathrm{OHA}$ or $\left[{ }^{3} \mathrm{H}\right] \mathbf{d o p a}$

Each point represents the average for three experiments performed in triplicate. Bars represent S.D. $\square, 10 \mu \mathrm{Ci}$ of $\left[{ }^{3} \mathrm{H}\right] 4-\mathrm{OHA}$ plus $10^{-3} \mathrm{M}$-unlabelled 4-OHA; $\square, 5 \mu \mathrm{Ci}$ of $\left[{ }^{3} \mathrm{H}\right]$ dopa plus $5 \times 10^{-4} \mathrm{M}$-unlabelled dopa; $5 \mu \mathrm{Ci}$ of $\left[{ }^{3} \mathrm{H}\right]$ dopa plus $5 \times 10^{-4} \mathrm{M}$-unlabelled dopa preincubated for $24 \mathrm{~h}$.

\section{DISCUSSION}

This study clearly demonstrates that the number and the steric position of hydroxy groups, as well as the presence of substituents on the benzene ring, play a role both in the toxicity of phenols against cultured cell lines and in their autoxidation, when incubated in a culture medium at $37^{\circ} \mathrm{C}$. A good correlation $(r=0.711)$ exists between the half-lives of the di- and tri-phenols and their toxicities (Fig. 9). The triphenol 6-hydroxydopa undergoes complete oxidation within $2 \mathrm{~h}$ of incubation in culture medium; the $o$-diphenols DPA, dopa and TBC, and the $p$-diphenol HQ, do so within $20 \mathrm{~h}$. Therefore the triphenol is more toxic than are the diphenols.

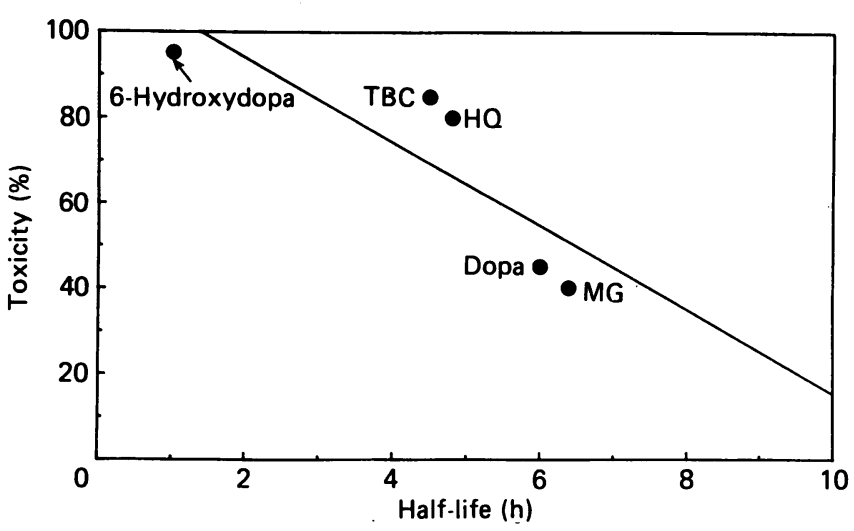

Fig. 9. Toxicity versus half-lives of $0.1 \mathrm{mM}$-tri- and -di-phenols

Linear regression was calculated by the method of least squares (correlation coefficient $=0.711$ ) from the values reported in Fig. 1 and Table 1. IRE 1, IRE 2 and K 562 cell lines showed the same behaviour as Raji cell line.

It is likely that the higher stability and the lower toxicity of MG, a triphenol commonly used as a food additive, compared with 6-hydroxydopa, depends upon the presence in position 1 of the molecule of a $-\mathrm{CO}_{2} \mathrm{H}$ group, which, because of its electron-acceptor property, partly stabilizes the molecule. The monophenols 4-OHA, BHA and tyrosine, and the diphenol RES, are stable enough in culture medium and therefore are less toxic under the same cultural conditions (Table 1). RES is an $m$-diphenol, which is not a substrate of tyrosinase because of the impossibility of its giving rise to a metaquinone (Passi \& Nazzaro-Porro, 1981). Probably the same impossibility accounts for its low degree of autoxidation. However, it must be pointed out that, because of their polarity, it is likely that monophenols enter the cells in higher amounts than do the corresponding diphenols, and these more so than triphenols.

The presence in the medium of oxygen-radicalscavenger enzymes produces two apparently contrasting effects in the case of triphenols and $o$ - and $p$-diphenols. On the one hand, SOD, CAT and PER, both individually or in association, increase the rate of decomposition (Fig. 2), but, on the other hand, they significantly decrease $(P<0.01)$ the adverse effect of phenols on all cell lines (Figs. 5 and 6). The contrast is easily explained by considering the latter aspect of the problem, that is, that the toxicity is modified by the presence of scavenger enzymes.

It is evident, from our results (Figs. 5 and 6), that the major component of the toxicity is attributable to active oxygen species acting outside the cells and not to the uptake of these phenols as such. It is known that rapidly autoxidating phenols generate oxygen-radical species, i.e. $\mathrm{H}_{2} \mathrm{O}_{2}, \mathrm{O}_{2}^{-\cdot}$ (superoxide radical), $\mathrm{OH}^{\cdot}$ (hydroxyl radical), and $\Delta^{1} \mathrm{O}_{2}$ (singlet oxygen), which are capable of damaging all types of cells (Graham et al., 1978; Hassan \& Fridovich, 1979; Thor et al., 1982). This may also explain why dihydric and trihydric phenols, all substrates for tyrosinase, do not show any specific toxicity against melanoma cell lines containing tyrosinase when compared with the other cell lines lacking tyrosinase (Table 1). In contrast, scavenger enzymes only slightly affect the toxicity of monophenols and RES, which are stable drugs. 
Stability experiments show that triphenols and diphenols undergo complete oxidation in culture medium within $24 \mathrm{~h}$ of incubation, yet cells added after 24 or $48 \mathrm{~h}$ preincubation are still killed (Fig. 7). Since the toxic role of oxygen radicals persists for about $24 \mathrm{~h}$ (Table 2), it is evident that, subsequently, other mechanisms must be involved, such as the disappearance from the medium of essential growth factors, which may be destroyed, or inactivated, by quinones, semiquinones and oxygen radicals formed during the autoxidation of phenols, and/or the possible concomitant formation of toxic radical polymers (Breathnach et al., 1983; Naish, 1984).

The lower toxicity of monophenols and RES is due, in our opinion, to the fact that they are less oxidized under the conditions existing in the culture medium and therefore do not produce sufficient levels of oxygen radicals. This is consistent with the observation that neither cell survival nor the rate of decomposition is significantly affected by the presence of scavenger enzymes. A primary intracellular action of these compounds has to be taken into account to explain their cytotoxicity.

Because of their relative non-polarity and greater liposolubility, BHA (not a substrate of tyrosinase) and 4-OHA (a substrate of tyrosinase) enter the cell more easily and therefore become more toxic (Table 1) than tyrosine (a substrate of tyrosinase) or the diphenol RES (not a substrate of tyrosinase), which are more polar.

The question of the cellular permeability to phenols is an important one, and, in our opinion, has not been adequately studied to date. The use of labelled compounds may give rise to misleading measurements and interpretations in this context. In fact the intracellular concentration of a compound is normally measured as ${ }^{3} \mathrm{H}$ or ${ }^{14} \mathrm{C}$ uptake (Wick \& Frei, 1977), without any further investigations into the localization and the chemical identity of the ${ }^{3} \mathrm{H}$ or ${ }^{14} \mathrm{C}$.

From our results (Fig. 8) it appears that no significant differences in ${ }^{3} \mathrm{H}$ uptake are found among the different cell lines cultured in the presence of $\left[{ }^{3} \mathrm{H}\right] 4-\mathrm{OHA}$; the behaviour is the same in the presence of $\left[{ }^{3} \mathrm{H}\right]$ dopa. The values for ${ }^{3} \mathrm{H}$ uptake of just-prepared dopa parallel those of dopa preincubated for $24 \mathrm{~h}$, when this catechol is fully decomposed, and are significantly higher than those obtained with [ $\left.{ }^{3} \mathrm{H}\right] 4-\mathrm{OHA}$ (1500 c.p.m. as against 950 c.p.m.), although this monophenol was added at double the concentration $(10 \mu \mathrm{Ci}$ as against $5 \mu \mathrm{Ci})$ and is more apolar than dopa. The point is that the ${ }^{3} \mathrm{H}$-uptake method does not give a reliable measurement of the entry of phenols into the cells.

In conclusion these results demonstrate that the fate and mechanism of cytotoxicity of phenols in culture have to be more critically evaluated before considering their possible use in man (mainly diphenols) for the 'selective chemotherapy of malignant melanoma'.

This work was supported by grants from the C.N.R. Italy (Project 'Oncology', no. 85.02270.44) and from Schering A.G., Berlin, Germany.

\section{REFERENCES}

Breathnach, A. S., Robins, E., Ethrige, L., Bhasin, Y., Gallagher, S., Passi, S. \& Nazzaro-Porro, M. (1983) Br. J. Cancer 47, 813-822

Fitzgerald, G. B. \& Wick, M. M. (1983) J. Invest. Dermatol. 80, 119-123

Fitzgerald, G. B. \& Wick, M. M. (1986) Biochem. Pharmacol. 35, 271-275

Fujita, K., Ito, S., Yamamoto, Y., Takeuti, J., Shamoto, M. \& Nagatsu, T. (1980) Cancer Res. 40, 2543-2549

Graham, D. G., Tiffany, S. M., Bell, W. R., Jr. \& Gutkenecht, W. F. (1978) Mol. Pharmacol. 14, 644-653

Hassan, H. M. \& Fridovich, I. (1979) Arch. Biochem. Biophys. 196, 385-396

Naish, S. (1984) in Hydroxyanisole: Recent Advances in Antimelanoma Therapy (Riley, P. A., ed.), pp. 83-100, IRL Press, Oxford

Parson, P. G. (1985) Biochem. Pharmacol. 34, 1801-1807

Parson, P. G. \& Morrison, L. (1982) Cancer Res. 42, 3783-3788

Passi, S. \& Nazzaro-Porro, M. (1981) Br. J. Dermatol. 104, 659-665

Passi, S., Nazzaro-Porro, M., Picardo, M. \& Breathnach, A. S. \& Riley, P. A. (1985) in Proceedings of the Twelfth International Pigment-Cell Conference, Giessen (Bagnara, J., Klaus, S. N., Paul, E. \& Scharlt, M., eds.) pp. 761-768, University of Tokyo Press, Tokyo

Pawelek, J. M. \& Lerner, A. B. (1978) Nature (London) 276, 627-628

Pawelek, J. M. \& Murray, M. (1986) Cancer Res. 46, 493-497

Picardo, M., Passi, S., Nazzaro-Porro, M., Breathnach, A. S., Zompetta, C., Faggioni, A. \& Riley, P. A. (1987) Biochem. Pharmacol. 36, 417-425

Riley, P. A. (1985) in Hydroxyanisole: Recent Advances in Antimelanoma Therapy (Riley, P. A., ed.), pp. 1-11, IRL Press, Oxford

Thor, H., Smith, M. T., Hartzell, P., Bellomo, G., Jewell, S. A. \& Orrenius, S. (1982) J. Biol. Chem. 257, 12419-12425

Wick, M. M. (1977) Nature (London) 269, 512-513

Wick, M. M. (1978) Science 199, 775-776

Wick, M. M. (1979) Cancer Treat. Rep. 63, 991-997

Wick, M. M. (1980a) Cancer Res. 40, 1414-1418

Wick, M. M. (1980b) J. Invest. Dermatol. 74, 63-65

Wick, M. M. (1982) Cancer Treat. Rep. 66, 1657-1659

Wick, M. M. \& Frei, E., III (1977) Cancer Res. 37, 2123-2125

Wick, M. M., Byers, L. \& Frei, E., III (1977) Science 197, 468-469

Wick, M. M., Rosowsky, A. \& Ratliff, J. (1980) J. Invest. Dermatol. 74, 112-114 